\title{
Krystyna Buchta
}

University of Physical Education in Warsaw, Biała Podlaska branch e-mail: krystyna.buchta@awf-bp.edu.pl

\section{Monika Jakubiak}

Maria Curie-Sklodowska University, Lublin

e-mail:monika.jakubiak@umcs.pl

\section{Małgorzata Skiert, Adam Wilczewski}

University of Physical Education in Warsaw, Biała Podlaska branch

e-mails: malgorzata.skiert@awf-bp.edu.pl; adam.wilczewski@awf-bp.edu.pl

\section{UNIVERSITY SOCIAL RESPONSIBILITY - THEORY VS. PRACTICE ${ }^{1}$}

\section{SPOLECZNA ODPOWIEDZIALNOŚĆ UCZELNI - TEORIA A PRAKTYKA}

\section{DOI: $10.15611 /$ pn.2018.520.02}

JEL Classification: I23, J24, M14

Summary: The subject matter of the present paper pertains to issues associated with the significance of university social responsibility. The paper outlines theoretical concepts and results of own studies connected with activities undertaken by a socially responsible university. Actions which take stakeholders' expectations into consideration are regarded as responsible. Consequently, vocational training of university graduates constitutes the focus of the paper. Results of own studies indicated several discrepancies between the expected and acquired competences of university graduates.

Keywords: university, university's social responsibility, graduates, employers.

Streszczenie: Problematyka artykułu dotyczy wybranych zagadnień odnoszących się do istoty społecznej odpowiedzialności szkoły wyższej. W pracy przedstawiono założenia teoretyczne oraz wyniki badań własnych odnoszące się do działań społecznie odpowiedzialnej uczelni. Przyjmując za odpowiedzialne działania, które uwzględniają oczekiwania interesariuszy, skupiono się na problematyce przygotowania zawodowego absolwentów uczelni. Wyniki badań pokazały rozbieżności między oczekiwanymi a nabytymi kompetencjami absolwentów uczelni.

Słowa kluczowe: szkoła wyższa, społeczna odpowiedzialność uczelni, absolwenci, pracodawcy.

${ }^{1}$ The paper was compiled in the framework of DS.205 statutory research financed by the Ministry of Science and Higher Education. 


\section{Introduction}

The objective of the paper is to evaluate actions undertaken by universities in the context of social responsibility.

The paper is based upon own studies conducted among university students graduating from the Józef Piłsudski University of Physical Education in Warsaw, Biała Podlaska branch, the faculty members, graduates with 1-2 years' of work experience, and employers employing (or planning to employ) graduates of the university.

Theoretical concepts and results of own studies pertaining to activities undertaken by a socially responsible university were presented in order to offer answers to research questions. Actions which take stakeholders' (recipients of the educational service) expectations into consideration are regarded as responsible. Opinions of students, graduates and employers were of particular interest. Faculty members' opinions were also referred to. Conditions of studies and graduates' vocational training became the object of the analysis.

Conditions of studies were evaluated by students graduating from graduate studies and by faculty members of the studied university. A premise was made that the members of the academic community (teachers and students) ought to constitute a group striving to achieve a joint, strictly defined objective established in the university's strategy. Discrepancies in the evaluation of the level of the objective's realization were analyzed. The discrepancies constituted the basis for corrective measures to be undertaken and the university's responsibility towards internal stakeholders improved.

Empirical considerations also included issues regarding graduates' vocational training. Opinions of employers and graduates with between one and two years of work experience were evaluated.

The study sought to indicate discrepancies in respondents' opinions. A premise was made that these discrepancies may indicate the university's inefficiency in realizing its social responsibility towards the stakeholders. At the same time, the discrepancies ought to constitute a starting point for the improvement of relations between the university and its social environment, mainly labor market.

\section{University social responsibility - theoretical considerations}

The issue of social responsibility is well-grounded in the context of company-society relations. Corporate Social Responsibility (CSR) is understood as a voluntary inclusion of social and environmental issues into the commercial activity and relations with stakeholders. ISO 26000 standard stipulates that responsible actions include those which contribute to sustainable development and social health and wellbeing, take stakeholders' expectations into consideration, and conform with the existing legislation and international standards of behavior [PKN 2013]. 
CSR, defined as the art of satisfying stakeholders' expectations, has been increasingly applied to universities. University social responsibility may apply to the university's responsibility for the general good (society, economy, etc.), one associated with embracing respect for the world, or the responsibility for the realization of specific tasks of the university and their outcomes [Vasilescu et al. 2010; Kowalska 2009].

In case of universities perceived as public utility institutions, the following constitute the essence of social responsibility: development of young workforce, impact upon public opinion, care for own image and maintaining good relations with the socio-economic environment, including students [Cybal-Michalska 2015]. When designing its vision and mission, a socially responsible university ought to make references to actions benefiting its surrounding environment and stakeholders. In knowledge-based economy, it primarily pertains to graduates' training for performing professional roles [Andrzejczak 2015; Geryk 2010; Hall 2011; Iwankiewicz-Rak, Wrona 2006; Jawor, Szczupaczyński 2011; Kochanowski 2008; Szabłowski 2004], and developing relations with business and local government environments.

Therefore, the university, as a public institution, apart from offering education and conducting research, has a duty to respond to social and economic needs and generate the so-called added value to the society and economy [Białoń, Werner 2012]. In such a context, universities ought to care for establishing good relations with their surrounding environment, especially by the application of efficient communication. According to M. Geryk [2014], proper communication between the university and environment has become one of the fundamental tools for shaping social responsibility initiatives.

The responsibility for graduates' vocational training and the improvement of employability were indicated in the Bologna Declaration. The declaration includes guidelines obliging individual states to reform their higher education systems, especially as far as improving employability is concerned [Piróg 2014]. Universities' responsibility for education grew with the introduction of the National Qualifications Framework. The framework stimulated educational standards being abandoned and offered universities a greater autonomy. At the same time, the framework obliged universities to ensure the emergence of particular learning outcomes.

\section{Methods of research}

The objective of the present study was to evaluate activities of a university in the context of its social responsibility. The present paper analyses the university's responsibility for learning outcomes measured by the following:

a) the degree conditions of studying are satisfied to (opinions of final-year students and academic teachers),

b) graduates' vocational training (opinions of employers and graduates with between one and two years of work experience). 
Empirical data was obtained in the course of a survey study. The study regarding the university's obligations in terms of providing suitable conditions of studying was conducted among final-year students of the University of Physical Education in Warsaw, Biała Podlaska branch $(N=60)$ and teachers employed in the institution $(N=12)$. On the other hand, as far as vocational training is concerned, the study encompassed graduates who completed their studies in 2015 and $2016(N=39)$ and employers employing or planning to employ the graduates of the university $(N=88)$. The study was conducted in 2017. Sampling was purposive.

The evaluation of the university's activity in terms of conditions enabling studying was conducted based upon a list of 49 aspects associated with the realization of the educational process. Respondents were to evaluate the university's responsibility for the extent to which graduates are prepared for meeting the requirements of modern labor market. They were presented a list of 26 competences describing the graduate profile with regard to the selected aspects of knowledge, skills, attitudes and personal features. Employers determined the significance of competences required on labor market and their presence in university graduates they employed. Employers' opinions were also analyzed in relation to the graduates' self-assessment of competences they acquired. The evaluation was based upon a 5-point scale. In case of the significance, 1 denoted little significance and 5 - high significance. In case of achievements, 1 denoted low level and 5 - very high level.

The following research questions were formulated:

1. To what degree does the university satisfy the responsibility for conditions of studying?

2. Which graduate competence areas satisfy employers' expectations, and which ought to be improved?

3. To what extent does the university meet the criteria of social responsibility for graduates' vocational training?

When searching for answers to these questions, discrepancies among respondents' opinions were examined. Student's $t$-test was applied in order to verify the thesis on the existence of significant differences. A premise was made that the difference amounts to $p<0,05$. In addition, in order to identify discrepancies requiring the introduction of corrective measures the most, the Importance Performance Analysis (IPA) was applied [Sztejnberg 2008].

\section{University social responsibility - results of own studies}

The literature of the subject emphasizes that social responsibility has become an inherent element of modern university strategic management. Therefore, the analysis of the university's actions requires references to its strategy to be made.

The authors of the 2020 strategy of the Józef Piłsudski University of Physical Education in Warsaw (AWF strategy) made a reference to the traditional mission of universities- to discover the truth and transfer knowledge. They perceive pro- 
social activities in the following: conducting world-class research, high quality of education, openness to the surrounding environment, and broad cooperation with employers. In addition, the strategy features a postulate pertaining to graduates' readiness for co-creating knowledge-based economy on the basis of a wide spectrum of fields of studies featuring utilitarian content and applying innovative teaching methods.

As far as the AWF strategy is concerned, the conditions of studying and graduates' vocational training constituted the object of empirical studies.

\subsection{Assessment of conditions of studying}

The implementation of the Bologna Process stipulations and the application of the National Qualifications Framework resulted in a change of the approach towards teaching: from teacher-centered learning focusing on transferring expert knowledge to students, towards student-centered learning (SCL). As a consequence, the teacher became a coordinator in the learning process and the student assumed the role of an active participant. The idea of SCL brings students to the center of interest of the universities' management. The institution's task is to provide suitable learning conditions [Bugaj 2013].

Students and academic teachers were requested to assess the selected aspects of studying by means of a 5-point scale. Their answers formed the picture of the didactic offer and conditions of studying at the university as perceived by internal stakeholders. As far as the university responsibility is concerned, the analysis of significant discrepancies in respondents' answers was vital.

Among 49 evaluated aspects of studying, 16 proved to differ statistically. Academic teachers tended to offer higher scores. Considerable differences were present with regard to the comfort of accommodation in the dormitory (gap =1.31), break period between classes (1.03), and opportunities for participating in science clubs (0.91). The least pressing differences (nevertheless significant) were noted regarding the time of end-of-term examinations, attractiveness of curricula, and the operation of a plagiarism checker system.

In order to identify the conditions of studying which require priority corrective measures, the Importance Performance Analysis (IPA) was applied. The approach served to compile a grid categorizing students' and teachers' opinions.

Research results encompassing the conditions of studying as assessed by students and teachers were presented in a coordinate system ( $X$-axis - students; $Y$-axis teachers). Arithmetic means of scores given by both groups constitute intercepts.

Each pair of scores is represented by a point in a coordinate system and occupies a particular position in a specific quadrant (Figure 1).

Table 1 situates the evaluated conditions of studying in individual quadrants. Aspects located in the second quadrant require a closer scrutiny and priority treatment on the part of the university's management. The situation is even more 


\begin{tabular}{|c|c|}
\hline Quadrant 2 & Quadrant 1 \\
High expectations level & High expectations level \\
Low achievements level & High achievements level \\
\hline Quadrant 3 & Quadrant 4 \\
Low expectations level & Low expectations level \\
Low achievements level & High achievements level \\
\hline
\end{tabular}

Figure 1. Required (desired) and acquired competences in light of the IPA approach Source: own study based upon [Sztejnberg 2008, pp. 112, 113].

Table 1. Conditions of studying as perceived by students and teachers* in light of the IPA approach

\begin{tabular}{|l|c|c|c|c|}
\hline \multicolumn{1}{|c|}{ Specification } & $\begin{array}{c}\text { Students } \\
(N=60)\end{array}$ & $\begin{array}{c}\text { Teachers } \\
(N=12)\end{array}$ & Gap $^{* *}$ & Quadrant \\
\hline Operation of plagiarism checker system & 3.69 & 4.22 & -0.53 & 1 \\
\hline Time of end-of-term examinations & 3.47 & 3.80 & -0.33 & 1 \\
\hline Laboratory facilities & 3.72 & 4.40 & -0.68 & 1 \\
\hline Sanitary facilities & 3.62 & 4.17 & -0.55 & 1 \\
\hline Comfort of accommodation in the dormitory & 3.44 & 4.75 & -1.31 & 1 \\
\hline Attractiveness of curricula & 3.39 & 3.82 & -0.43 & 2 \\
\hline Applicability of acquired knowledge in prospective \\
careers & & & & \\
\hline Participation in science clubs & 3.03 & 3.75 & -0.72 & 2 \\
\hline Student grading system & 3.36 & 4.27 & -0.91 & 2 \\
\hline Classes timetable & 3.37 & 4.00 & -0.63 & 2 \\
\hline Break period between classes & 2.87 & 3.75 & -0.88 & 2 \\
\hline On-time announcement of exam results & 3.07 & 4.10 & -1.03 & 2 \\
\hline Internet access on campus & 3.35 & 4.10 & -0.75 & 2 \\
\hline Scope of practical classes & 3.08 & 3.73 & -0.64 & 2 \\
\hline Scope of available classes & 2.58 & 3.27 & -0.69 & 3 \\
\hline Availability of student internships & 2.68 & 3.55 & -0.87 & 3 \\
\hline
\end{tabular}

${ }^{*}$ Valid only for statistically significant differences; $p<0.05 ;{ }^{* *}$ difference between the student's and teacher's score.

Source: own study.

pressing when the fact that half of the assessed aspects is located here is highlighted. Interestingly, it is teachers who scored all attributes higher than students. Therefore, when evaluating the educational offer and conditions of studying, embracing the point of view of a single group would be misleading. 


\subsection{Graduates' vocational training - employers' point of view}

The literature of the subject highlights the existence of a clear asymmetry of information between employers and employees regarding the expected features of graduates on modern labor market [Piróg 2013]. The present paper attempts to verify the thesis empirically.

Employers were requested to select 26 features characterizing graduates. They assessed the vocational utility of the features on the one hand, and their level exhibited by graduates on the other. As far as the university's responsibility for graduates' vocational training is concerned, the establishment of features which manifested the strongest discrepancies was vital. The features are detailed in Figure 2. The size of competence gaps seen from employers' perspective was also included. Among 12 attributes manifesting statistically significant differences, the following presented the largest discrepancies: the graduates' utility regarding expert qualifications and licenses, experience acquired while studying, and the ability to apply knowledge in practice. Relatively smallest gaps were observed in case of the graduates' theoretical training.

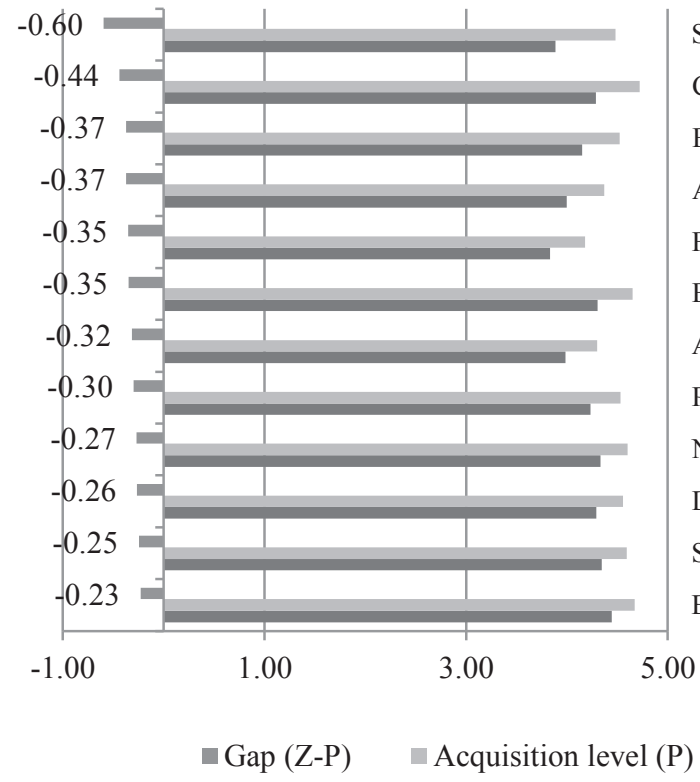

Specialist licenses and qualifications

Combining theory with practice

Experience acquired during studies

Additional courses and trainings

Familiarity with sector-related legal regulations

Effective time management

Ability to operate devices/equipment

Problem-solving skills

Need for learning and permanent development

Decision-making skills

Specialist course-related knowledge

Broad course-related/general knowledge

.00

- Competence significance $(\mathrm{Z})$

Figure 2. Significance of competences at work vs. graduates' acquisition level as perceived by employers

Source: own study.

The study also attempted to compare opinions of employers regarding the significance of the analyzed attributes of graduates' vocational training in recruitment 
and selection with the self-assessment of these features conducted by student respondents. Figure 3 outlines only respondents' divergent opinions regarding the matter $(p<0.05)$. Among 8 indicated gaps, the largest discrepancies pertained to the following: familiarity with specific sector-related regulations, and acquired professional experience. Personal features of graduates (assertiveness, problemsolving skills) differed from the level expected by employers much less.

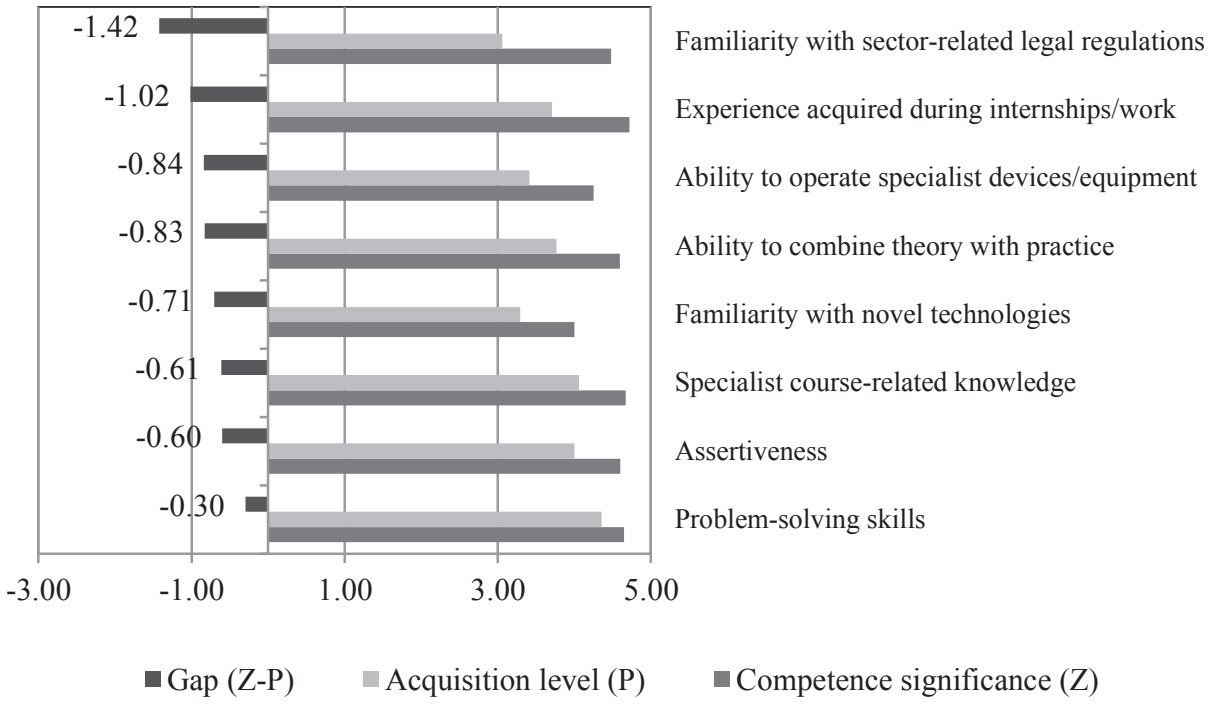

Figure 3. Competences required at work vs. graduates' self-assessed acquisition level

Source: own study.

The study of university social responsibility also analyzed the issue of criteria and rules applied in recruitment and selection. The convergence of employers' and graduates' opinions was tested (Figure 4). According to employers, the following are significant: completed field of studies, proper content-related knowledge, and vocational experience. As far as graduates are concerned, the result of the job interview is the most critical. Statistically significant differences pertained to three of the assessed aspects. Graduates highlighted the role the diploma of a particular university played ( $47 \%$ vs. $10 \%$ of employers), development of professional supporting job application documents (41\% vs. 10\%), and the significance of the final grade on the diploma ( $17.6 \%$ vs. $4.5 \%)$. 


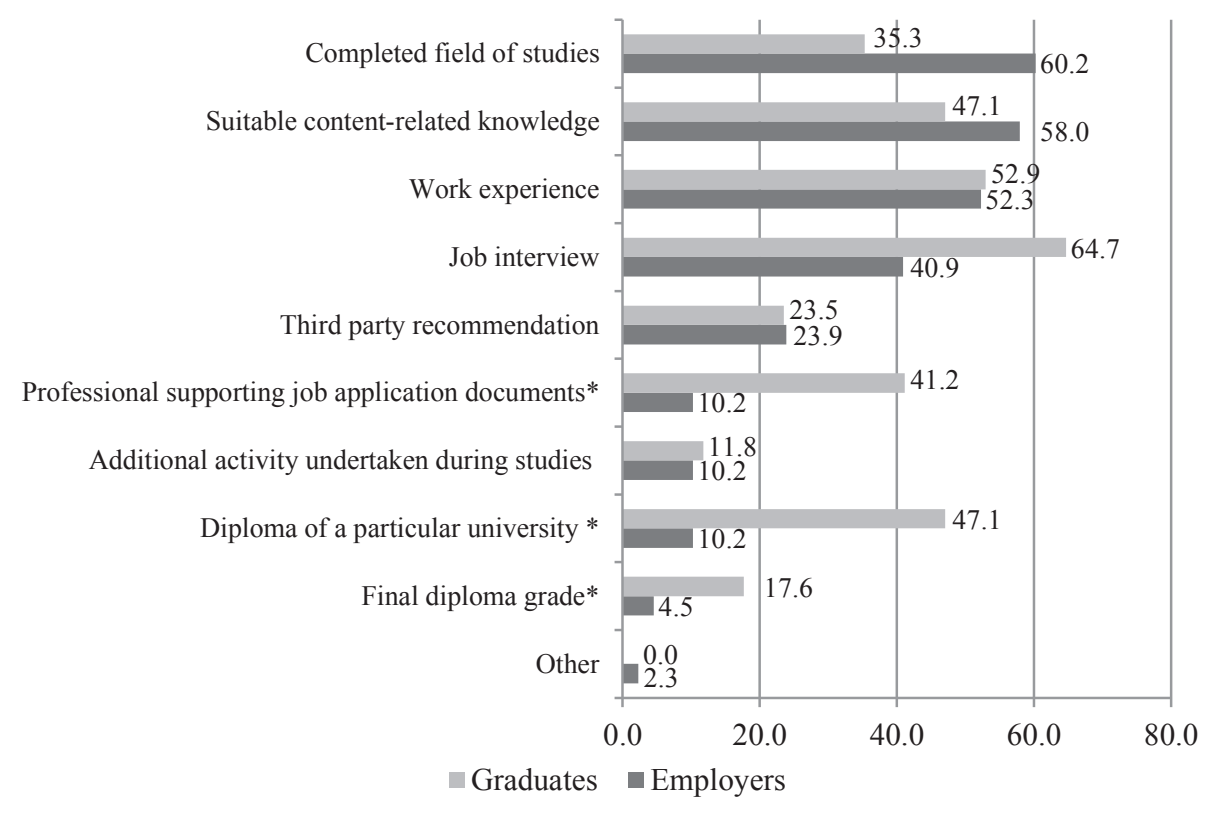

*Difference between the student's and teacher's score.

Figure 4. Criteria applied in recruitment and selection as evaluated by employers and graduates (\%) Source: own study.

\section{Conclusions}

The subject matter of the present study pertains to the concept of university social responsibility. The paper makes a premise that CSR constitutes a long-term idea of developing social trust as a result of needs of stakeholders being satisfied, enabling organizational objectives to be achieved and social problems solved [Kazojć 2014].

The discussion of university social responsibility aims to establish solutions facilitating the emergence of the greatest possible synergy in the course of universityenvironment relations [Van Ginkel 2002; Rajaoson 2002; Välimaa, Hoffman 2008].

Based upon the premise that CSR revolves around multi-dimensional relations, the paper analyses CSR activities undertaken with internal stakeholders in mind and those going beyond the organization itself. Due to the fact that students and faculty members are considered as the most important internal stakeholders, it was this group that became respondents in the study aiming to assess the university's responsibility for conditions of studying. Results obtained in the course of the study revealed several discrepancies in the way studies are perceived by students and teachers. However, the intensity and scope of convergence between the way the university is managed and stakeholders' expectations seems a necessity in the way the socially responsible 
institution functions. In light of the above, the improvement of communication between the elementary constituting groups co-forming the academic community seems essential. This also stems from references present in AWF strategy stipulating the "necessity of developing clear procedures for evaluating methods and learning conditions [AWF 2012].

The empirical study encompassed the issue of the university's responsibility towards external stakeholders as well. Results of the analysis pertaining to the university's obligation in the context of graduates' vocational training revealed several discrepancies as far as the perception of the quality of the university's product, i.e. graduates, is concerned.

The present results of own studies are convergent with results of studies conducted in other academic institutions. Several discrepancies between employers' expectations and graduates' competences are indicated. These differences hinder the transition from the university onto the labor market [Wronowska 2015; Werner 2011]. The OECD report highlights the necessity of a stronger outward and social needs focus of Polish higher education system. This can be achieved by e.g. inclusion of employers and representatives of local governments in advisory bodies for higher education [Fulton et al. 2007, pp. 46, 47].

It seems that the improvement of the university-labor market relations requires a systematic assessment of ever-changing employers' expectations. In addition, a responsible university is obliged to offer reliable information on the results of such an assessment.

In conclusion, it ought to be noted that limitations associated with purposive sampling do not allow the results to be generalized to reflect the whole academic community. However, they enable the following final remarks to be made. The remarks constitute answers to the research questions.

Several discrepancies were observed regarding the perception of conditions of studying expressed by students and academic teachers. Teachers tended to offer higher scores.

1. Employers believe that the greatest gap between the utility of the selected competences and their level exhibited by the employed graduates pertained to the following: the acquired expert qualifications and licenses, work experience, and the application of knowledge in practice.

2. The self-assessment of acquired competences conducted by graduates diverges significantly from the level required by labor market. The greatest discrepancies were observed with regard to the familiarity with specific legal regulations, and acquired work experience.

The present empirical study encompassed the analysis of selected aspects of university social responsibility. Further research may be conducted to incorporate other CSR fields (e.g. relationship between stakeholders, employers, institutions, and examination of the general CSR spirit of universities). It would also be worthwhile to conduct comparative studies in this respect, e.g. among universities located in 
various parts of the country or between state and public universities. International comparative studies would also carry significant weight.

\section{References}

Andrzejczak A., 2015, Uniwersytet przedsiębiorczy i odpowiedzialny społecznie, Edukacja Ekonomistów i Menedżerów: Problemy, Innowacje, projekty, nr 38 (4), pp. 117-130, DOI: 10.5604/01.3001.0009.4658.

AWF, 2012, Strategia rozwoju Akademii Wychowania Fizycznego Józefa Pitsudskiego w Warszawie do roku 2020, http://awf.edu.pl/_data/assets/pdf_file/0020/14168/Strategia-rozwoju-Uczelni-do-roku-2020.pdf (12.12.2018).

Białoń L., Werner E., 2012, Społeczna odpowiedzialność szkoły wyższej w kontekście jej wizerunku, Nauka i Szkolnictwo Wyższe, nr 1(39), pp. 142-161.

Bugaj J., 2013, Kształcenie skoncentrowane na studentach tzw. Student Centered Learning (SCL): co się za tym kryje?, https://www.nauka.gov.p1/g2/oryginal/2013_05/b806803278fa7cf824c3e1cb6d2d09bf.pdf (10.01.2018).

Cybal-Michalska A., 2015, Społeczna odpowiedzialność uczelni wyższych, Rocznik Lubuski, nr 41(2), pp. 89-96.

Fulton O., Santiago P., Edquist C., El-Khawas E., Hackl E., 2007, OECD Reviews of Tertiary Education Poland, OECD, Paris.

Geryk M., 2010, Społeczna odpowiedzialność uczelni w percepcji jej interesariuszy. Raport z badań, Oficyna Wydawnicza SGH, Warszawa.

Geryk M., 2014, Rola skutecznej komunikacji z interesariuszami jako narzędzie ksztattowania polityki w zakresie społecznej odpowiedzialności uczelni, Prace Naukowe Uniwersytetu Ekonomicznego we Wrocławiu, nr 338, pp. 40-51.

Hall H., 2011, Dydaktyczne kryteria satysfakcji studenta - hierarchia i znaczenie w świetle wyników badań empirycznych, Prace Naukowe Uniwersytetu Ekonomicznego we Wrocławiu, nr 237, pp. 209-219.

Iwankiewicz-Rak B., Wrona S., 2006, Jakość kształcenia - czynniki i kryteria oceny, [in:] Nowaczyk G., Lisiecki P. (eds.), Marketingowe zarządzanie szkoła wyższa, Wydawnictwo Wyższej Szkoły Bankowej w Poznaniu, Poznań.

Jawor A., Szczupaczyński J., 2011, Efekty kształcenia jako centralna idea Krajowych Ram Kwalifikacji, Przegląd Socjologiczny, nr 4(60), pp. 67-86.

Kazojć K., 2014, Koncepcja społecznej odpowiedzialności i jej obszary w organizacjach, Zeszyty Naukowe Uniwersytetu Szczecińskiego, Studia i Prace Wydziału Nauk Ekonomicznych i Zarządzania, nr 38(1), pp. 57-70.

Kochanowski J., 2008, Komunikacyjny (polilogiczny) model zarządzania jakościa w szkole wyższej, Nauka i Szkolnictwo Wyższe, nr 31, pp. 85-98.

Kowalska K., 2009, Społeczna odpowiedzialność uczelni, Zeszyty Naukowe Małopolskiej Wyższej Szkoły Ekonomicznej w Tarnowie, nr 2, pp. 289-300.

Piróg D., 2013, Absolwenci szkót wyższych na rynku pracy w warunkach kryzysu, Przedsiębiorczość Edukacja, nr 1(9), pp. 302-316.

Piróg D., 2014, Konkurowanie uniwersytetów na rynku ustug edukacyjnych w warunkach kryzysu gospodarczego i nasilajacych się trudności tranzycji absolwentów, Prace Komisji Geografii Przemysłu Polskiego Towarzystwa Geograficznego, nr 28, pp. 115-128.

PKN, 2013, ISO 26000 Guidance on social responsibility. Norma międzynarodowa dotyczaca spolecznej odpowiedzialności, https://www.pkn.pl/informacje/2013/09/iso-26000 (20.11.2017). 
Rajaoson F., 2002, Academic freedom and social responsibility reflections from the African experience, Higher Education Policy, vol. 15, pp. 375-379.

Szabłowski M., 2004, Poziom nauczania jako dylemat marketingowy uczelni, [in:] Nowaczyk G., Kolasiński M. (eds.), Marketing szkół wyższych, Wydawnictwo Wyższej Szkoły Bankowej w Poznaniu, Poznań.

Sztejnberg A., 2008, Doskonalenie ustug edukacyjnych, Podstawy pomiaru jakości ksztatcenia, Uniwersytet Opolski, Opole.

Välimaa J., Hoffman D., 2008, Knowledge society discourse and higher education, Higher Education, vol. 56, pp. 277-278.

Van Ginkel H., 2002, Academic freedom and social responsibility - the role of university organizations, Higher Education Policy, vol. 15, pp. 347-351.

Vasilescu R., Barna C., Epure M., Baicu C., 2010, Developing university social responsibility: A model for the challenges of the new civil society, Procedia-Social and Behavioral Sciences, 2(2), pp. 4177-4182.

Werner E., 2011, Absolwent szkoły wyższej - sylwetka w kontekście społecznym, Nauka i Szkolnictwo Wyższe, $\mathrm{nr}$ 37(1), pp.106-118.

Wronowska G., 2015, Oczekiwania na rynku pracy. Pracodawcy a absolwenci szkół wyższych w Polsce, Studia Ekonomiczne. Zeszyty Naukowe Uniwersytetu Ekonomicznego w Katowicach, nr 214, pp. 115-127. 